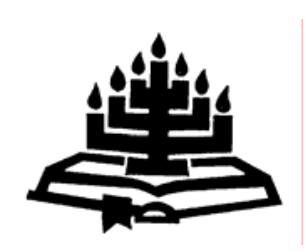

\title{
Reëling van die Gereformeerde predikant se diens - 'n arbeidsregtelike of 'n interne kerklike aangeleentheid?
}

\author{
J. Smit \& A. le R. du Plooy \\ Skool vir Kerkwetenskappe \\ Potchefstroomkampus \\ Noordwes-Universiteit \\ POTCHEFSTROOM \\ E-pos: johannes.smit@telkomsa.net \\ 10055878@nwu.ac.za
}

\begin{abstract}
Regulation of a Reformed minister's office - a labour law or internal church matter?

In this article it is argued that Labour Law is not applicable on the relationship between a minister and a church council to the Reformed Churches in South Africa. The main focus of the argument is that Labour Law does not have the purpose to regulate a relationship based on an exegetic-dogmatically founded foundation. It is also argued that a minister in the Reformed Churches in South Africa cannot be considered an employee of the church council because of the calling he received from the Lord. The calling of a minister is the main indication that he is not an employee of the church council, but a servant of the Lord. Therefore it is also stated that the Church Order does not regulate the minister's office on a contractual basis, but that the Church Order regulates the calling of a minister. Labour Law intents to regulate the labour aspect of a person's life while the Church Order applies to a minister's whole life.
\end{abstract}

\section{Opsomming}

Reëling van die Gereformeerde predikant se diens - 'n arbeidsregtelike of ' $n$ interne kerklike aangeleentheid?

In hierdie artikel word aangedui dat die Arbeidsreg nie op die verbintenis tussen 'n predikant en 'n kerkraad in die Gereformeerde Kerke in Suid-Afrika toegepas behoort te word nie. Daar word geargumenteer dat die Arbeidsreg nie ten doel het 
om 'n eksegeties-dogmaties bepaalde verhouding, soos dié tussen die kerkraad en predikant te reël nie. Verder word daarop gewys dat 'n predikant van die Gereformeerde Kerke in Suid-Afrika nie as 'n werknemer van die kerkraad beoordeel kan word nie, aangesien 'n predikant 'n geroepe dienskneg van Christus is. Die roeping van 'n predikant is 'n belangrike aanduiding dat 'n predikant nie 'n werknemer van 'n kerkraad is nie, maar in diens van die Here staan. Daar word eweneens aangedui dat die Kerkorde nie die predikantsdiens op 'n kontraktuele basis reël nie, maar die roeping van 'n predikant. Arbeidsreg het ten doel om arbeidsregtelike aspekte van 'n persoon se lewe te reël, terwyl die reëlings van die Kerkorde van toepassing is op 'n predikant se hele lewe.

\section{Aktualiteit en probleemstelling}

Die aktualiteit van dié tema word beklemtoon deurdat SuidAfrikaanse howe ná 1996 die diens van predikante met betrekking tot arbeidswetgewing op verskillende wyses benader. Twee resente hofuitsprake beklemtoon die verskillende benaderings van howe ten opsigte van dié aspek. In 1999 het regter Basson in die Schreudersaak bevind dat 'n predikant 'n werknemer van 'n kerkraad is:

'n Predikant van die Nederduitse Gereformeerde Kerk is dus die werknemer van die gemeente waarin hy of sy diens doen en voor Oktober 1998 het so 'n predikant ook nog sekondêre werkgewers gehad, dit wil sê, die betrokke ring en die betrokke sinode (tot 'n mindere mate). (Schreuder $v$ Nederduitse Gereformeerde Kerk Wilgespruit \& others 199920 ILJ 1936 (LC) op 1942; kyk ook 1940, 1941.)

Hierdie uitspraak hou in dat die predikantsdiens gereël moet word met die volledige inagneming van bestaande arbeidswetgewing (Olivier, 2002:11). Voordat die hof uitspraak in die Schreuder-saak gelewer het, het die Nederduitse Gereformeerde Kerk (NGK) sy kerkorde so gewysig dat predikante voortaan as werknemers van die "gemeente of kerkverband (ring, sinode of Algemene Sinode)" optree (NGKO: art. 12). Die verandering van die NG Kerk se kerkorde het ongetwyfeld bygedra tot die hof se bevinding dat die predikant (ds. Schreuder) 'n werknemer van die kerkraad is (Schreuder v Nederduitse Gereformeerde Kerk Wilgespruit \& others 199920 ILJ 1936 op 1941).

In 2001 het regter Wagley in die volgende saak, Church of the Province of Southern Africa (Diocese of Cape Town), bevind dat 
daar nie 'n arbeidsverhouding tussen 'n predikant en 'n kerkraad bestaan nie:

... I am satisfied that there was in fact no intention ... to enter into a legally enforceable employment contract.

Since I have found that a contract of employment is necessary for purposes of establishing an employment relationship and that there was no legally enforceable contract of employment between the applicant and the third respondent, the parties are not an employer and employee as defined by the LRA and consequently the first respondent has no jurisdiction to entertain the alleged dispute referred to it by the third respondent. (Church of the Province of Southern Africa (Diocese of Cape Town) v CCMA \& others [2001] 11 BLLR 1213 (LC) op 1227.)

Volgens die Kaapse Arbeidshof is die diens van 'n priester/predikant 'n kerkregtelike verbintenis. ${ }^{1}$ Dié verbintenis word deur die Anglikaanse Kerk by wyse van hulle kerkgemeenskap se konstitusie kerklik gereël. Hierdie reëling word eerbiedig op grond van die "intensie van die partye" - volgens die hof het die kerk en die priester nie die intensie gehad om hulle verbintenis kontraktueel te reël nie.

Een van die belangrikste regte wat godsdiensvryheid aan die kerk bied, is die reg van kerklike selfdefiniëring (vgl. Smit, 2006:633-651). Die kerk het die reg om homself en interne kerklike dienste te definieer. Dit beteken dat die kerk die reg het om by wyse van selfdefiniëring 'n keuse uit te oefen vir die toepassing van die arbeidsreg op die predikant se diens, al dan nie (vgl. Olivier, 2002:531-542). Die hof het nie die bevoegdheid om regsverbintenisse te skep nie en moet ook nie vanweë 'n onvoldoende selfdefiniëring van die kerk in 'n posisie gestel word om (onbedoeld) so 'n verbintenis te skep nie (vgl. Church of the Province of Southern Africa (Diocese of Cape Town) v CCMA \& others [2001] 11 BLLR 1213 (LC) op 1213 e.v.).

In die genoemde hofuitsprake het die Nederduitse Gereformeerde Kerk en die Anglikaanse Kerk hulle onmiskenbaar op verskillende

1 Die begrip kerkregtelike verbintenis dui op die bronne van die verbintenis, naamlik die Skrif, die belydenis en die kerkorde, sowel as die predikant se persoonlike verbintenis met God. In hierdie artikel gaan dit juis om die verbintenis waarin God die predikant in sy gemeente stel én oor die wyse waarop die verbintenis deur die kerkorde gereël word. 
wyses gedefinieer. Hierdie selfdefiniëring van die onderskeie kerkgemeenskappe was van deurslaggewende belang om te bepaal of die predikant/priester as werknemer van die kerkraad beoordeel moet word, al dan nie. Die kernvraag vir hierdie ondersoek word soos volg geformuleer: Dui die selfdefiniëring van die Gereformeerde Kerke in Suid-Afrika daarop dat die reëling van Gereformeerde predikante se diens 'n arbeidsregtelike of ' $n$ interne kerklike aangeleentheid is?

Hierdie probleemstelling word aan die hand van die volgende leidende vrae uitgewerk:

- Wat is die intensie van die Suid-Afrikaanse Arbeidsreg ten opsigte van die predikantsdiens, soos dit by wyse van wetgewing tot uitdrukking kom?

- Wat is die aard en doel van die Gereformeerde kerkregering met betrekking tot die predikantsdiens, soos dit by wyse van die Kerkorde gereël word?

- Is die Gereformeerde predikant se diens van so 'n aard dat hierdie diens by wyse van die arbeidsreg of by wyse van die Gereformeerde Kerkorde gereël behoort te word?

\section{Moontlike regsgevolge van die Suid-Afrikaanse arbeidswetgewing vir die predikantsdiens}

\subsection{Ontwikkeling van die arbeidsreg}

As gevolg van die Industriële Rewolusie het mense op groot skaal in fabrieke gewerk. In hierdie omstandighede het litigasie tussen werkgewers en werknemers al hoe meer voorgekom. Vanweë die skraal ontwikkeling in die Romeins-Hollandse arbeidsreg (waar slawe gekoop en nie aangestel is nie) is allerweë in arbeidsregspraak veral op die regsgesag in Engeland gesteun. Die gevolg was 'n amalgamasie tussen die Romeins-Hollandse en die Engelse reg ten opsigte van arbeidswetgewing. Op grond van hierdie amalgamasie het nuwe beginsels vir die arbeidsreg ontstaan (Grogan, 2000:3; Jordaan \& Rycroft, 1994:34, voetnoot 183).

Die arbeidsreg word na die regsoort locatio conductio van die Romeins-Hollandse reg herlei. Daar word onderskei tussen drie soorte locatio conductio, naamlik locatio conductio rei, locatio conductio operis en locatio conductio operarum (vgl. Grogan, 2000:2-3, voetnoot 2; Berger, 1953:568, 567; Jordaan \& Rycroft, 1994:43). Die locatio conductio rei dui op die huur of verhuur van 
iets met geldelike vergoeding as deel van die ooreenkoms. Die begrip locatio conductio operis is die voorganger van die hedendaagse begrip van onafhanklike kontrakteur, terwyl die locatio conductio operarum dui op die huur of verhuur van persoonlike diens teen vergoeding (remuneration).

Die sentrale lyn wat deur die onderskeie vorms van locatio conductio loop, is dat iets gehuur en/of verhuur word (Grogan, 2003:2 e.v., 19). Die begrip van 'n arbeidsverhouding het uit die locatio conductio operarum ontwikkel (vgl. Grogan, 2003:2 e.v.). So 'n verbintenis ontstaan wanneer 'n persoon sy dienste teen vergoeding aan 'n ander persoon of instansie verhuur én sy diens onder die toesig van sodanige werkgewer verrig (vgl. Grogan, 2003:16). So 'n reëling beteken dat die sentrale vraag vir die definiëring van 'n predikant se diens die volgende is: Huur 'n kerk die dienste van 'n predikant en/of verhuur 'n predikant sy dienste aan 'n kerk?

\subsection{Wetlike bepalings}

In die Suid-Afrikaanse Grondwet word redelik omvattende bepalings oor arbeidswetgewing gemaak (GW: art. 23). Die Grondwet (GW: art. 23) waarborg die regte van werkgewers én werknemers redelik breedvoerig (vgl. Du Plessis, 1997:25). Die eerste reg wat deur Artikel 23 gewaarborg word, is dat elkeen die reg op billike arbeidspraktyke het (GW: art. 23(1)). Die belangrikste regte van werknemers is om vakbonde te stig (GW: art. 23 (2)a), daarby aan te sluit (GW: art. 23(2)b) en om aan die bedrywighede van sulke organisasies deel te neem (GW: art. 23, (2)b, vgl. (2)c).

Die belangrikste regte van werkgewers is dus om werkgewersorganisasies (eie organisasies) te stig, by sulke organisasies aan te sluit en aan die bedrywighede daarvan deel te neem. Werkgewers en werknemers het albei die grondwetlike reg om kollektief te beding (GW: art. 23(5); vgl. Du Plessis, 1997:25). Die grondwetlike bepalings oor Arbeidsreg word prakties uitgevoer by wyse van die volgende "hoofstroom"-wetgewing oor arbeidsreg, naamlik Die Wet op Arbeidsverhoudinge 66 van 1995, die Die Wet op Basiese Diensvoorwaardes 75 van 1997 en Die Wet op Gelyke Indiensneming 55 van 1998. 


\subsection{Doel van spesifieke arbeidswetgewing}

\subsubsection{Die Wet op Arbeidsverhoudinge 66 van 1995}

Die doel van die Die Wet op Arbeidsverhoudinge 66 van 1995 is om ekonomiese ontwikkeling, sosiale geregtigheid, werksvrede en die demokratisering van die werkplek te bevorder (Die Wet op Arbeidsverhoudinge 66 van 1995, hoofstuk 1 s. 1). Die primêre doelwitte van die Wet word soos volg geformuleer:

(a) to give effect to and regulate the fundamental rights conferred by section 27 of the Constitution;

(b) to give effect to obligations incurred by the Republic as a member state of the International Labour Organisation;

(c) to provide a framework within which employees and their trade unions, employers and employers organisations can -

(i) collectively bargain to determine wages, terms and conditions of employment and other matters of mutual interest; and

(ii) formulate industrial policy; and

(d) to promote -

(i) orderly collective bargaining;

(ii) collective bargaining at sectoral level;

(iii) employee participation in decision-making in the workplace; and

(iv) the effective resolution of labour disputes.

Hierdie wet bevat bepalings wat kollektiewe bedinging en die oplossing van dispute aanmoedig. Ook bepaal die wet spesifieke reëls en regte wat deur die Kommissie vir Versoening, Bemiddelling en Arbitrasie (KVBA) of die howe bereg kan word indien teenstrydighede ontstaan of beperkings daarop toegepas word. Vir hierdie bepaling van reëls en wette word die gesag van die forums wat vir hierdie doel daargestel is, uitgebrei. Die KVBA het byvoorbeeld die bevoegdheid van bemiddeling en arbitrasie. Indien ' $n$ dispuut nie deur bemiddeling opgelos word nie, word die saak na die Kommisaris van die KVBA, of afhangende van die aard van die dispuut, na die Arbeidshof verwys. Verder gee die Die Wet op Arbeidsverhoudinge 66 van 1995 onder meer die reg aan werk- 
nemers om te staak. Ook die posisie van vakbonde en werkplekforums word deur dié wet bepaal.

\subsubsection{Die Wet op Basiese Diensvoorwaardes 75 van 1997}

Die doel van die Die Wet op Basiese Diensvoorwaardes 75 van 1997 is om ekonomiese ontwikkeling en sosiale geregtigheid te bevorder deur aan die volgende primêre doelwitte van die Wet uitvoering te gee:

(a) to give effect to and regulate the right to fair labour practices conferred by section 23 (1) of the Constitution -

(i) by establishing and enforcing basic conditions of employment; and

(ii) by regulating the variation of basic conditions of employment;

(b) to give effect to obligations incurred by the Republic as a member state of the International Labour Organisation.

Hierdie wet bevat bepalings oor diensvoorwaardes wat die wetgewer as van fundamentele belang beskou. Hierdie diensvoorwaardebepalings sluit bepalings in oor onder meer werksure, voldoende pouses tydens die werksdag, siekteverlof, voorskrifte oor ekstra betaling, ensovoorts. Verder stel die wet 'n diensvoorwaardekommissie daar met die opdrag om advies aan die minister te gee. 'n Werksinspeksie-afdeling is verantwoordelik om dispute in ooreenstemming met die wet te hanteer. Die wet gee ook aan die minister die bevoegdheid om sectoral determinations te maak, soos byvoorbeeld die bepaling van minimum lone. Die Wet op Basiese Diensvoorwaardes 75 van 1997 bepaal ook dat slegs die Arbeidshof jurisdiksie oor aangeleenthede met betrekking tot die wet het.

\subsubsection{Die Wet op Gelyke Indiensneming 55 van 1998}

Die doel van die Die Wet op Gelyke Indiensneming 55 van 1998 is om diskriminasie uit te wis en gelykheid in die werksplek te bevorder deur die volgende maatreëls toe te pas:

(a) promoting equal opportunity and fair treatment in employment through the elimination of unfair discrimination; and

(b) implementing affirmative action measures to redress the disadvantages in employment experienced by designated groups, in order to ensure their equitable repre- 
sentation in all occupational categories and levels in the workforce.

Sleutelbegrippe in hierdie wet is ekonomiese ontwikkeling, sosiale geregtigheid, werksvrede en demokratisering van die werksplek. Met die beklemtoning van hierdie kernvereistes van arbeidswetgewing poog die staat om die "onregte van die verlede" in die arbeidsektor reg te stel, nuwe ontwikkelings in die arbeidsreg te akkommodeer en die moontlikheid van 'n beter toekoms vir alle Suid-Afrikaners te skep (vgl. Grogan, 2003:6-7 e.v.). Daar word eweneens gepoog om die verhouding van mag en ondergeskiktheid wat tussen 'n werkgewer en 'n werknemer mag bestaan, uit te skakel. ${ }^{2}$ Volgens die tradisionele werkgewer-werknemerbeskouing het 'n werkgewer die verpligting om aan 'n werknemer sy loon te betaal, terwyl 'n werknemer nie op veel meer aanspraak kan maak nie. 'n Werknemer is gewoonlik nie in 'n posisie om voor te skryf wanneer die verhouding bepaal word nie (Jordaan \& Rycroft, 1994:21, 23-26).

Wanneer die oogmerke van die arbeidswetgewing verreken word, ontstaan verskeie vrae oor 'n predikant se diens:

- By wie berus die gesag in 'n kerk? Is daar op grond van die gereformeerde gesagsbeskouing 'n juridies bepaalde gesagsverhouding tussen 'n kerkraad en 'n predikant?

- Is die kerk op grond van sy oorsprong, wese en doel 'n demokratiese instelling (soos byvoorbeeld 'n societas), waarin die beginsels van die demokrasie bepalend is vir die kerkregering en vir die reëling van 'n predikant se diens?

- Kan die doel van kerkwees bereik word met die reëling van predikante se diens as 'n interne kerklike aangeleentheid, indien die bepalings van arbeidswetgewing vir die reëling van hierdie posisie geld?

\subsection{Moontlike kerkregtelike gevolge vir die predikantsdiens}

Die Wet op Arbeidsverhoudinge 66 van 1995, Die Wet op Basiese Diensvoorwaardes 75 van 1997 en Die Wet op Gelyke Indiens-

2 Dit is algemeen bekend dat die gesagsverhouding as kenmerk van 'n werkgewer-werknemerverbintenis nie meer deur alle navorsers aanvaar word nie. Vir die doeleindes van hierdie artikel word aanvaar dat daar altyd ' $n$ mate van gesag deur 'n werkgewer oor 'n werknemer uitgeoefen word. 
neming 55 van 1998 word op alle werkgewer-werknemerverhoudings toegepas. Die genoemde wette het nie noodwendig toepassing op werkers van die volgende organisasies nie:

- die Nasionale Weermag;

- die Nasionale Intelligensie Agentskap;

- die Suid-Afrikaanse Geheime Diens; en

- die Suid-Afrikaanse Akademie van Intelligensie

Olivier (2002:537) wys daarop dat mense wat nie volgens die wetlike definisie as werknemers beskou word nie, steeds die regte in Artikel 23 van die Grondwet het. In South African National Defence Union v Minister of Defence 1999 BCLR 713 (LC) het die Konstitusionele Hof beslis dat lede van die Nasionale Weermag as werkers beskou moet word (South African National Defence Union v Minister of Defence 1999 BCLR 713 (LC) par. 24-29). Die Konstitusionele Hof het die betekenis van die begrip werknemer in arbeidswetgewing op grond van internasionale arbeidsregtelike bepalings uitgebrei om lede van die Nasionale Weermag te akkommodeer onder Artikel 23 van die Grondwet (South African National Defence Union v Minister of Defence 1999 BCLR 713 (LC) par. 24-29).

Die moontlikheid bestaan dus dat howe ook met betrekkking tot predikante se diens die betekenis van die begrip werknemer kan uitbrei en op predikante kan toepas. Uit die Schreuder-saak en die Church of the Province of Southern Africa (Diocese of Cape Town)saak is dit duidelik dat howe hulle hoofsaaklik deur kerklike dokumente en spesialiteitsgetuienis laat lei het om predikante se diens te beoordeel. Die selfdefiniëring van die kerk is dus van deurslaggewende belang om te oordeel of die predikant in 'n juridies-bepaalde arbeidsverhouding diens verrig.

\section{Aard en doel van die Gereformeerde kerkregering met betrekking tot die predikantsdiens}

\subsection{Bronne van die Kerkorde}

Die bronne van die Kerkorde (kyk Smit, 2007:584 e.v.) wat gebruik word om die diens van die predikant te bepaal, is die Heilige Skrif, die belydenis en die kerkreg. Die fokus val in hierdie opsig op die verhouding tussen die Skrif, die belydenis en die kerkorde. Hierdie bronne is in beginsel ook die maatstaf vir die geldigheid van die 
kerkorde en uit hierdie bronne word aangetoon dat die Woord onafhanklik van staatsbepalings funksioneer (vgl. Smit, 1984c:6974).

\subsubsection{Betekenis van die Skrif vir die reëling van die predikantsdiens}

Die vraag wat beantwoord moet word, is watter gesag die kerkorde het om die diens van die predikant te reël, in teenstelling met die gesag van arbeidswetgewing. In die gereformeerde kerkreg word aanvaar dat die die Heilige Skrif die belangrikste bron vir die reëling van die kerklike orde is (Van der Walt, 1976:161; Bouwman, 1970a:324, 325; vgl. Sillevis Smitt, 1910:114; Pont, 1981:9; Smelik, 1973:58, 59). In die Skrif word die beginsels gegee waarvolgens die kerkorde opgestel moet word (vgl. Calvyn, 1991: Inst. 4.10.30, 1525). 'n Noodsaaklike deel van hierdie orde vir die kerk is die reëling van die kerklike dienste (vgl. 1 Kor. 9; 2 Tess. 3:6 e.v.; 1 Tim. 3:113; 2 Tim. 2:14 e.v.; NGB: artt. 30-32; KO: artt. 3-19). Onder hierdie dienste neem die reëling van die predikant se diens 'n belangrike plek in. Dié diens word byvoorbeeld eerstens deur die kerkorde gereël (KO: artt. 4-17).

Die kerkorde is nie 'n selfstandige regspostulering naas die Skrif wat regsgeldigheid gee aan die Skrifbepalings oor predikante se diens nie (vgl. Calvyn, 1991: Inst. 4.10.30, 5-35; Milner, 1970:192). Dit beteken dat die kerkorde nooit naas die Skrif as gesagsbron te staan kom nie (Smit, 1984c:83; vgl. Smit, 1984b:39 e.v.; Smit, 1984a:41 e.v.). Volgens hierdie vertrekpunt het die kerkorde nie selfstandige, wetlike gesag nie. Die kerkorde skep nie die reg om die predikant se diens te reël nie, maar gee slegs uitvoering aan die opdrag van die Here. Die Skrif stel byvoorbeeld sekere vereistes vir bedienaars in die kerk (1 Tim. 3:5; 5:19) en gee sekere opdragte oor die onderhoud van bedienaars van die Woord (Matt. 10:10; Gal. 6:6; Fil. 4:15; 2 Tess. 3:9; vgl. HK: Son. 38; Sillevis Smitt, 1910:180181). Die gesag van die kerkorde om predikante se diens weer te gee, berus primêr daarop dat die kerkorde norma ministrans, 'n bediening van die gesag van die Skrif is (Smit, 1984c:83). Die verpligting van die kerk om die diens van predikante te reël, is gesetel in die opdrag wat die Here vir sy kerk gee. Die Skrif vervul in hierdie opsig dus vir die kerk die funksie wat die staat deur arbeidswetgewing vir die burgerlike gemeenskap beoog. 


\subsubsection{Betekenis van die belydenis vir die predikantsdiens}

Die belydenisskrifte van die kerk verwoord die Skrifbeginsels van die kerk. Die reëling van predikante se diens is deel van die kerk se belydenis, dit wil sê die kerk se reëlings oor hierdie aangeleentheid is deel van die homologein (om dieselfde te sê) van die Skrif (Polman, s.a.:6, 7; vgl. Smit, 1984a:45). Die belydenis bied dus die beginselbasis, die grondreël waarop kerke in kerkverband die predikant se diens in doctrina (leer) en disciplina (ordening) onderhou (vgl. Du Plooy, 1982:238). Die plek van die dienste en die wyse waarop die kerkregering gereël word, kom spesifiek in Artikels 28-31 van die Nederlandse Geloofsbelydenis na vore.

Volgens die belydenis mag die predikant nie as 'n werknemer van 'n kerkraad beskou word nie:

- Die diens van die predikant word verbind aan die geestelike bestuurswyse van die kerk (NGB: art. 30). In ooreenstemming met hierdie siening is 'n predikant nie ' $n$ werknemer van die "huisgesin van God nie", maar 'n bestuurder in die gemeenskap van die gelowiges. 'n Predikant is saam met die ouderlinge kubernéseis (stuurmanne) en hégoumenoi (leiers) wie se taak dit is om leiding in die gemeente te gee (proshistamenos) (Du Plooy, 1979:54, 55).

- Die wyse waarop die bestuurstaak van die kerk uitgeoefen word, is eweneens 'n belangrike aanduiding dat die predikant se posisie nie beoordeel mag word as dié van 'n werknemer van die kerk nie. Die predikant is saam met die ouderlinge nie 'n heerser oor die erfdeel nie, maar 'n voorbeeld vir die gelowiges; 'n herder, 'n dienskneg wat aan die Opperherder rekenskap moet gee - 'n rentmeester van God (Du Plooy, 1979:56).

- Verder stel die belydenis die fundamentele Skrifbeginsel van roeping tot die predikantsdiens as maatstaf vir die reëling en beoordeling van predikante se diens (NGB: art. 31). Die belydenis sê dat 'n ampsdraer (predikant) moet wag totdat hy deur God geroep word, sodat hy van sy roeping oortuig kan wees en sekerheid kan hê dat dit van God kom (NGB: art. 31). Vanweë die verhouding tussen die kerkorde en die belydenis, waardeur die kerkorde die beginsels van die belydenis prakties in die Gereformeerde Kerkorde reël, het die kerkorde die doel om die roeping van die predikant te reël (vgl. KO: art. 4, 5). Dit beteken dat die belydenis (doctrina) en die regering (disciplina) van die kerk nie van mekaar geskei kan word nie, omdat dissipelskap juis 
die gevolg is van die verkondiging van die doctrina wat Christus aan ons geleer het (Du Plooy, 2002:4).

Die roeping van die predikant word geaktiveer deur die bevestiging in die plaaslike kerk (vgl. NGB: art. 30). In hierdie opsig moet die roeping en die bevestiging in verhouding tot mekaar verstaan word, aangesien die bevestiging niks anders is as die bevestiging van die roeping nie. Hierdie innige band tussen die predikant en die Here dra die stempel van 'n huwelik. Sodoende is die geloofsverbintenis wat deur die bevestiging tot stand kom 'n essensieel emosionele aangeleentheid wat in terme van 'n spesifieke geloofsorde, in hierdie geval die Kerkorde van die Gereformeerde Kerke, gereël word. Die diens van die Gereformeerde predikant, soos dit in die Kerkorde van die Gereformeerde Kerke in Suid-Afrika gereël word, word dus bepaal deur die roeping wat van die Here kom asook die feit dat die Kerkorde uitsluitlik die doel het om die roeping van die predikant te reël. In die arbeidsreg en in die staatsreg word nie voorsiening gemaak om so 'n geloofsband te reël nie.

\subsection{Aard en doel van die Kerkorde}

In die Gereformeerde kerkreg is die Kerkorde die ius constitutum (die reg soos dit is) (Van der Linde, 1965:123). Volgens hierdie uitgangspunt is die ius constitutum die vormgewing van reg deur beginsels uit die Woord af te lei soos dit deur tyd, plek en omstandighede beïnvloed word. Hierdie reg word uit die ius constituendum afgelei. Die ius constituendum is die ideële opvatting van die beginsels van die kerkreg, soos dit deur die kerkreg in die Skrif nagevors en steeds verder in die lig gestel word (Smit, 1984d:73; vgl. Van der Linde, 1965:123). Die Gereformeerde kerkreg definieer die reg van die kerk dus as 'n selfstandige reg. Hierdie beskouing van die reg bied die perspektief dat die kerk die diens van die predikant reël op grond van die selfstandige reg van die kerk. Hierdie selfstandige reg is inherent deel van die kerk se beskouing oor kerklike orde en die bediening van sodanige orde. Volgens hierdie vertrekpunt word die diens van die predikant gereël deur die interne (privaat) reg van die kerk (vgl. Gildenhuys, 2001:226; Pienaar, 1982:215-216, 254-255).

\subsection{Toepassingsveld van die Kerkorde}

Die uitgangspunt van Artikel 1 van die Kerkorde wat in die Gereformeerde Kerke in Suid-Afrika toegepas word, bied die konteks waarbinne die kerkordelike bepalings oor die predikant se diens 
verstaan moet word. In Artikel 1 van die Kerkorde word die volgende bepaal:

Om goeie orde in die kerk van Christus te onderhou, is daarin nodig: die dienste, samekomste, toesig oor die leer, sakramente en seremonies en die kerklike tug, waaroor hierna agtereenvolgens gehandel word.

Hierdie uitgangspunt benadruk dat dit die uitsluitlike doel van die Gereformeerde Kerkorde is om reëlings vir die instandhouding en opbou van die kerk te tref (Calvyn, 1991: Inst. 4.10.27; 4.11.1). Die reëlings met betrekking tot die predikant se diens moet binne hierdie konteks verstaan word. Volgens die Kerkorde word die reëling van predikante se diens noodwendig as ' $n$ interne kerklike aangeleentheid beskou, omdat die predikantsdiens deel is van die orde wat die Here vir die opbou en instandhouding van sy kerk gee (vgl. Calvyn, 1991: Inst. 4.3.1.1-10):

He calls forth ministers to be fellow-labourers, by means of whom He alone works; but at the same time in such a way, that they at their turn labour in common with him. (Calvin, 1848:131, 132.)

Die eiesoortige reëlings van die predikant se diens in die kerkorde verteenwoordig die kerk se selfstandige geloofsorde waarin die hoofskap van Jesus Christus oor die kerk na vore kom (vgl. Smit, 1984c:120). Die kerkorde verbind die predikant in die eerste plek nie aan die kerk nie, maar aan die hoofskap van Jesus Christus in die kerk, en sodoende is hierdie verbintenis van die predikant binne die raamwerk van die kerk deel van die harmonieuse orde: "die ... evenwichtig coördinatensysteem, waarin ambt en gemeente niet met elkaar op gespannen voet staan, maar waarin beide de plaats innemen, die God hun binnen het geheel toewees" (Van't Spijker, 1990:157). Die kerkordelike reëlings vir die predikant se diens, waardeur sy diens kerkordelik omlyn word, is integraal deel van die ordelike bestaanswyse van die kerk in die wêreld (vgl. Van't Spijker, 1990:157).

\section{Diens van die Gereformeerde predikant}

\subsection{Prinsipieel-aktueel}

\subsubsection{Oorsprong}

Uit die Nuwe Testament blyk dat die diens van die predikant 'n spesifisering van die diens van die ouderlinge is (Sillevis Smitt, 
1910:158 e.v.; 180, 181; Van Ginkel, 1975: hoofstuk 1; Berkhof, 1976:386). Die ouderling is volgens die Nuwe Testament presbuteros (Hand. 20:17; Tit. 1:5), episkopos (Hand. 20:28; Tit. 1:7) en poimen (Hand. 20:28; 1 Pet. 5:2). Verskeie teoloë dui daarop dat die begrippe presbuteroi en episkopoi in die Nuwe Testament as sinonieme gebruik word (Versteeg, 1982:11-20; Van Bruggen, 1984:78-98; Van der Linde, 1965:62, 63). Volgens Van der Walt (1976:74 e.v.) kom die werk van die ouderling daarin tot uitdrukking dat hy die gemeente moet "oppas" en "laat wei". Die werkwoord poimanein (om soos 'n herder op te pas) dui spesifiek op die werk van die ouderlinge (Du Plooy, 1979:53).

Omdat die diens van die ouderlinge deur die apostels ingestel is, is dit nie nodig om die spesifieke tydstip waarop die diens ingestel is, aan te toon nie. Hierdie instelling deur die apostels dui reeds daarop dat die besondere diens ooreenkomstig die wil van Christus ingestel is (Van der Linde, 1965:59; Van Genderen, 1982:64, 65; Berkhof, 1976:586; vgl. Versteeg, 1982:30; Bavinck; 1930:371). As voortsetting van die diens van die apostels, geld die spesifieke ooreenkoms tussen die dienste dat:

Hierdie ampte, deur die apostels as die gevolmagtigdes van Christus ingestel, ... [kom] daarin ooreen met die apostoliese amp dat deur die vervulling van die diens daarin opgedra, Christus in sy kerk gestalte moet kry (Van der Linde, 1965:55).

Deur die instelling van die besondere dienste het Christus 'n eenmalige reëling getref wat bepalend vir die kerk se bestaanswyse in die geskiedenis is (Du Plooy, 1979:52; Bouwman, 1970a:346); Van der Linde, 1978:44; Spoelstra, 1971:27). Sonder die besondere dienste, ook dié van die predikant, kan die kerk nie as die liggaam van Christus op aarde voortbestaan nie.

\subsubsection{Opdrag en taak van die Gereformeerde predikant}

Wie tot diens in die kerk van die Here geroep word, ontvang ook sy opdrag wat hy moet uitvoer van die Here (vgl. NGB: art. 31). Die opdrag van die predikant om die evangelie te verkondig, word nie deur die kerkraad bepaal nie, met ander woorde die kerkraad bepaal nie die diens wat deur die predikant gelewer moet word nie. Die predikant en die kerkraad is gesamentlik besig met die diens wat Christus deur die roeping aan hulle opdra (vgl. Visser, 1982:202).

Volgens Calvyn se interpretasie van Matteus 16:17-19 en 18:17 moet die potestas ecclesiae drievoudig verstaan word. Die kerk het die bevoegdheid om die potestas doctrinae, die postestas iuris- 
dictionis en die potestas in legibus ferendis te formuleer en te bedien. Die disciplina ecclesiae is hiervolgens deel van die postestas iurisdictionis. Die bediening van die sleutels van die koninkryk behels dus meer as die bediening van die kerklike tug, terwyl die kerklike tug altyd 'n bediening van die sleutels van die koninkryk is (Du Plooy, 1998:54, 55). Die potestas wat die predikant as deel van die kerkraad besit, is dus die bevoegdheid om die sleutels van die koninkryk te bedien (vgl. Van't Spijker, 2001a:3).

Die doel van hierdie bediening is die opbou van die kerk (Calvyn, 1991: Inst. IV.8.1; IV.11.1; IV.10.) In sy diens beywer die predikant hom vir die verkondiging van die evangelie van Christus, en hy doen dit in ooreenstemming met die wyse wat Christus in sy Woord bepaal. Die kerkraad is eweneens besig om hulle vir die saak van Christus te beywer (Van't Spijker, 2001b:2). Die predikant en die kerkraad is op grond van hulle roeping besig om die evangelie in die wêreld in diens van Christus te verkondig. As diensknegte van Christus is die predikant en die kerkraad aan Christus onderwerp:

Die dienaar wat sy (Christus se) gesag bedien, is slegs ' $n$ werktuig in sy hand. En 'n werktuig kan niks anders doen nie as om hom te onderwerp aan wie hom hanteer. (Smit, 1985:97.)

Die eiesoortige posisie van die predikant kom tot stand op grond van die feit dat sy posisie bepaal word as dié van leer- en regeerouderlinge. As bedienaar van die Woord moet die predikant die leerdiens vervul. In die uitvoering van hierdie diens het die predikant die taak om voor te gaan in die diens van die gebede en in die bediening van die Woord en sakramente (KO: art. 16). Die predikant is egter saam met die ouderlinge ook regeerouderling - hierdie uitgangspunt impliseer dat hy saam met die kerkraad verantwoordelik is vir die toesig oor die leer en die lewe van die lidmate (KO: art. 23). Op grond van hierdie vertrekpunt word die eiesoortige reëling van die predikant se diens aangedui as 'n niehiërargiese, maar wel 'n gemeenskaplike taakvervulling van die predikant saam met die ouderlinge (vgl. Pel et al., 1991:12, 13).

Die staat mag nie invloed uitoefen op die reëlings met betrekking tot die predikant se diens nie. Die taakaanduiding en taakvervulling van die predikant funksioneer as die kerk se deurslaggewende aanduiding dat die staat nie die reg het om die predikant se diens by wyse van arbeidswetgewing te reël nie. 


\subsubsection{Doel van die predikantsdiens}

As dienskneg van Christus het die predikant die taak om die kudde wat God aan sy sorg toevertrou, te versorg, te lei en te beskerm. Die diens van die predikant verkry 'n geestelike of geloofsdimensie deurdat sy taak (verpligtinge) geheel en al in diens van die Here staan en by wyse van Skrifbepalings deur die Here verorden word. Sy "verpligtinge" word beseël deur sy belofte aan God, terwyl sy "regte" ook bepaal word op grond van die agting wat die gemeente aan hom verskuldig is (Formulier, 2001:137-142). Op grond van die genoemde geestelike of geloofsdimensie verkry die predikant se diens, deur sy verbintenis aan die plaaslike kerk, geheel en al 'n ander aard as dié van 'n werknemer teenoor sy werkgewer. Die gesagsverhouding word deur die bevestiging van die predikant ook nie gestel as dié van kerkraad oor predikant nie; die gesagsverhouding word eksplisiet aangedui as 'n gesagsverhouding van die Here teenoor sy dienaar en 'n verhouding wat verseël word deur die predikant se belofte aan die Here.

\subsection{Prinsipieel-prakties}

\subsubsection{Roeping}

Die verbintenis tussen Christus en die predikant is die hoeksteen op grond waarvan die diens van die predikant gedefinieer word. Hierdie verbintenis word in die Kerkorde gereël by wyse van bepalings oor die beroeping van die predikant (KO: artt. 4,5$)$. Die beroeping én die roeping van die predikant moet verstaan word as twee aspekte wat dieselfde gewig en belangrikheid het. Die roeping van die predikant kan bondig beskryf word as die begeerte om die evangelie van Christus lewenslank te verkondig (Van der Linde, 1983:13; Vorster, 1999:18), terwyl die beroeping van die predikant uitdrukking gee aan die wyse waarop hierdie roeping prakties in die kerk gereël word (KO: artt. 4, 5). Op grond van hierdie omskrywing kan twee aspekte vir die reëling van die predikant se diens deur die Kerkorde gestel word:

- Deur die roeping is die diens van die predikant 'n lewenslange diens. Die Kerkorde reël nie slegs een aspek soos byvoorbeeld die diensverhouding van 'n predikant se lewe nie (vgl. Pel et al., 1991:13). In hierdie opsig verskil die bepalings van die Kerkorde wesenlik met dié van arbeidswetgewing. Die doel van arbeidswetgewing is om 'n werksverhouding tussen twee partye juridies te reël (vgl. Die Wet op Gelyke Indiensneming, Wet 55 van 1998 (1(1)). Op grond van die bepalings van die arbeidsreg het die 
werkgewer nie die reg om aanspraak op of inspraak in aspekte van die werknemer se lewe buite die juridies-bepaalde arbeidsverhouding te maak nie. In die kerklike lewe het kerke die reg om aanspraak te maak op en inspraak te hê in die predikant se lewe. Hierdie reg is daarop gegrond dat die leer en die lewe van die predikant nie van mekaar geskei kan word nie (Jak. 2:14-26; vgl. 1 Tim. 3:1-13).

- Die bepalings van die Kerkorde oor die predikant se diens vervang nie die staat se arbeidswetgewing nie, maar reël 'n godsdiensbepaalde verbintenis met 'n ander doel en inhoud as die bepalings van die arbeidsreg. Deur die roeping wat van die Here uitgaan, word die predikant in 'n direkte verhouding met die Here gestel (Van der Linde, 1980:31, 32). Die Een wat roep, bepaal nie slegs die diens wat deur die predikant verrig word nie (Van der Linde, 1987:19), maar neem die predikant in geheel vir die uitvoering van sy taak "in diens". In ooreenstemming met hierdie uitgangspunt behels die roeping van die predikant nie slegs 'n geestelike dimensie nie. Die roeping is omvattend - die geroepene word as volledige mens in diens van die Here van die kerk gestel (vgl. Coenen, 1986:274). "Die Here neem die wat Hom dien in sy vertroue en maak sy verbond aan hulle bekend." (Ps. 25:14.)

\subsubsection{Beroeping}

Deur 'n predikant te beroep word die roeping op 'n ordelike wyse in die plaaslike kerk gereël. Omdat God sy Woord en Gees ook deur die dienste aan die gemeente gee, moet die roeping tot die dienste van God deur middel van die gemeente kom (Richel, 1942:199). Die dienste, waaronder dié van die predikant se diens, word derhalwe aan die plaaslike kerk verbind (vgl. Goumaz, 1964:21; Smit, 1985: 99).

Die beroeping deur die gemeente is die bevestiging van die predikant se innerlike roeping. Aangesien Christus nie meer sy diensknegte direk roep soos in die geval van die apostels nie, is die roeping slegs kenbaar in die ooreenstemming van die innerlike en uiterlike roeping. Deur die beroeping erken die kerk dat God die enigste vocator primarius is en bly (Vorster, s.a.:30). In die kerk van die Here is daar net Één wat roep. Volgens die beginsel van roeping mag daar nie aan die kerk meer gesag toegeken word as wat dit toekom nie. Die kerk mag dus nie verselfstandig word asof dit die kerk is wat die predikant roep en nie die Here nie. Vir die predikant is die vocatio externa, die middellike roeping deur die gemeente 
(Van der Linde, 1965:55), niks anders nie as die roepstem van God (Van't Spijker, 1987:368) en 'n bevestiging van die innerlike roeping (vgl. Paul, 1965:154, 156). Volgens hierdie vertrekpunt is die beroeping van die predikant deel van die orde in die gemeente en 'n instelling van die kerk se regering. Die kerk moet hierdie orde dus nougeset handhaaf (Calvyn, 1991: Inst. 4.3.10.1-20).

Dit is belangrik om daarop te let dat die bevoegdheid wat die plaaslike kerk ontvang om die predikant te verkies, volledig in die Skrif setel (Calvyn, 1991: Inst. 4.3.15). God gee die gawe aan 'n gemeente om 'n bedienaar tot die diens te roep. Die verkiesing van 'n predikant deur 'n gemeente beteken dat so 'n gemeente die gawes wat Christus aan die bedienaar van die Woord gee, opmerk, en die persoon aanwys wat vir die diens geroep is (vgl. Philip, 1979:22). Deur hierdie opdrag na te kom, toon die gemeente dat hulle instrumenteel in die roeping van die predikant is. Die beroeping van die predikant deur die gemeente verskuif dus nie die fokus van die Here wat roep na die gemeente wat beroep nie.

Die beroeping van die predikant kan in werklikheid nie beskryf word as 'n mensbepaalde roeping nie, maar wel as 'n werking van die Gees in die hart van die predikant en in die midde van die gemeente (Calvyn, 1991: Inst. 4.3.14. par. 10-15). Só bevestig die beroeping van die predikant eerder die feit dat die predikant geroep word tot die diens van die Here in die gemeente van die Here.

\subsubsection{Bevestiging van die predikant}

Die bevestiging is na die roeping, eksaminering en beroeping die Here se finale aanwysing en "bemagtiging" van die dienaar om die diens in die Naam van die Here te mag uitvoer (kyk Van't Spijker, 1970:101; Bouwman, 1970a:408 e.v.). Sodoende word die roeping van die predikant bevestig en word die predikant in staat gestel om as dienaar van die Here in die kerk op te tree (kyk Bouwman, 1970a:408 e.v.).

Die formulier is ingedeel in 'n inleiding, 'n kort uiteensetting oor die instelling en taak van die predikant se diens, die vrae waarop die predikant bevestigend moet antwoord, 'n vermaning gerig tot die gemeente en 'n slotgebed. In die inleiding word die bevestiging van die predikant verbind aan die bepalings van die Kerkorde. In die uiteensetting oor die instelling en taak van die predikantsdiens word die beginsels gestel dat Christus mense tot besondere dienste roep en die dienste in en aan die kerk gee. Verder word gestel dat die predikant as herder en leraar van die gemeente 
... die kudde wat God aan [sy] sorg toevertrou, ... [moet] versorg, lei, en beskerm. [Hy] moet dit doen deur die verkondiging van die Woord, die bediening van die sakramente, die diens van die gebede en deur te help met die regering van die kerk (Formulier, 2001:137-142).

Met hierdie verbesondering van die aard van die predikantsdiens word die Woordverkondiging aangedui as die sentrale taak van die predikant.

Volgens die Formulier is daar geen aanduiding dat die predikant (as 'n werknemer) in diens van die plaaslike kerk bevestig word nie. Met die eerste vraag van die Formulier word eerder die teendeel bewys. Tydens die bevestiging word goddelike en menslike faktore geheimnisvol saamgevoeg om die predikant in diens van Christus te bevestig (vgl. Spoelstra, 1989:32). Spoelstra (1989:52) wys daarop dat die kerk by die handeling van beroep iemand wat Christus aan hulle gee "... in diens van Christus stel sonder dat hulle hom in diens neem". Wat tot dusver oor die bevestiging van die predikant en predikantsdiens gesê is, dui daarop dat Christus die predikant tydens die bevestiging "in diens neem" en nie die plaaslike kerk waarin die predikant bevestig word nie.

'n Verdere aanduiding dat die predikant nie as 'n werknemer deur die kerkraad in diens geneem word nie, is die belofte wat 'n predikant tydens die bevestiging aflê. Hierdie belofte dui daarop dat die diens van die predikant bepaal word deur sy instemming met die geloofsposisie soos dit in die Gereformeerde kerkreg en die Gereformeerde kerkregering tot vergestalting kom. Met die bevestigende antwoord op die vyfde vraag word die diens van die predikant in beginsel bepaal as ' $n$ interne kerklike aangeleentheid.

Die predikant onderneem om hom aan die kerklike vermaning en tug te onderwerp indien hy in leer of lewe van die leer afwyk. Hierdie monopleuriese aard van die Formulier het nie die kenmerke van ' $n$ kontraktuele ooreenkoms nie. (Monopleuries dui op 'n aktiwiteit wat slegs van één party uitgaan.) In 'n kontraktuele ooreenkoms onderhandel twee gelyke vennote met mekaar totdat 'n gemeenskaplike ooreenkoms bereik word. Die Formulier wys eerder op die duidelike Skrifbepalings van die Here waaraan die dienaar, kragtens sy roeping, verbind word en waaraan die predikant hom tydens die bevestiging onderwerp (vgl. Pienaar, 1986:34). Verder word die diens van die predikant daardeur bepaal dat hy tydens die bevestiging nie deur die kerk of kerke in diens geneem word nie, 
maar in staat gestel word om die opdrag wat hy van die Here ontvang, in diens van die Here as Opdraggewer uit te voer.

Die doel van die Formulier is nie om 'n arbeidsverhouding tussen die kerkraad en die predikant te skep nie. Die bevestiging volgens die Formulier konstitueer 'n eiesoortige geloofs- en 'n diensverhouding in die eksegeties-dogmatiese sfeer van die kerk. Die diens van die predikant word omvattend deur die geloof bepaal. Op hierdie wyse word die predikant vir die uitvoering van sy diens, in diens van Christus bevestig. Die doel van hierdie diens is om die plaaslike kerk deur die verkondiging van die evangelie op te bou (vgl. Smit, 2001:25-27).

\section{Gevolgtrekking}

Arbeidswetgewing het in die algemeen die billike en regverdige reëling van werkgewers en werknemers se posisie in die werksplek ten doel. Deur arbeidswetgewing beoog die staat om die ongelykheid tussen 'n werkgewer en 'n werknemer uit die weg te ruim. Sodoende poog die staat om harmonie in die werksplek te bring. Verder word daarop gewys dat die arbeidswetgewing deur 'n ekonomiese doelstelling beheer word, soos gedefinieer deur die strydbeginsel tussen 'n werkgewer en 'n werknemer. Die verhoudings in die kerk word nie op grond van stryd beslis nie, maar deur die liefdesopdrag wat Christus vir die kerk gee. Die arbeidsreg maak nie daarvoor voorsienning om 'n komplekse eksegeties-dogmatiese verhouding te reël nie. Die arbeidsreg reël bloot ' $n$ faset van 'n persoon se lewe, terwyl kerkordelike reëlings oor 'n predikant se diens sy hele lewe omvat.

In die lig van die selfdefiniëring van die Gereformeerde Kerke in Suid-Afrika blyk dat die predikantsdiens wesenlik eiesoortig is. Die eiesoortige posisie van die predikant word veral beklemtoon deur die kerkordelike reëlings waardeur die regsposisie van die predikant as 'n geloofsverbintenis gereël word. Die volgende bepalings is deurslaggewend vir die beoordeling van die predikant se regsposisie: die bepalings oor die verhouding tussen die kerk en die predikant, die verhouding tussen die kerkraad en die predikant, die taakomskrywing van die predikant, die versorging van die predikant, die betekenis van die beroepsbrief, die kerkordelike bepalings oor die tug en die beginsel dat meer kerke die predikant se roeping en die uitlewing van sy roepingstaak moet beoordeel.

Soos die roeping van die predikant 'n aanduiding is dat die predikant nie in diens van die kerk staan nie, maar in diens van Christus, is die 
traktement wat die predikant ontvang, 'n aanduiding dat die predikant nie in 'n kontraktuele verhouding met die kerk staan nie. Die aard en omvang van die traktement wat die predikant van die kerkraad ontvang, word nie bepaal deur 'n vrywillige ooreenkoms nie, maar rus op ' $n$ Skrifbegronde verpligting van die gemeente. Die traktement wat die predikant ontvang, is derhalwe nie 'n vrywillige ooreenkoms tussen die kerkraad en die predikant nie, maar die uitvoering van die Skrifopdrag dat hulle wat die evangelie verkondig, ook van die evangelie moet leef.

So gesien, voldoen die predikant se regsposisie, soos dit deur die Kerkorde gereël word, nie aan sekere fundamentele vereistes om 'n kontrak tussen die kerkraad en die predikant tot stand te bring nie. Die doel van hierdie verbintenis is byvoorbeeld nie om 'n kontrak tussen die kerkraad en die predikant te sluit nie, maar om uitvoering aan die Skrifopdrag te gee deur die roeping van die predikant te reël. Op hierdie wyse kom 'n godsdiensbepaalde verbintenis tussen die predikant en die kerkraad tot stand. Die kerkraad en die predikant onderwerp hulle op grond van hulle gemeenskaplike belydenis aan die regering van Christus. Die reëling van die Gereformeerde predikantsdiens blyk, volgens die selfdefiniëring van die Gereformeerde Kerke in Suid-Afrika 'n interne kerklike aangeleentheid te wees, gegrond op godsdienstige bepalings en nie onderhewig aan die staat se arbeidswetgewing nie.

\section{Geraadpleegde bronne}

BAVINCK, H. 1930. Gereformeerde dogmatiek. Vierde Deel. 4e onveranderde druk. Kampen: Kok.

BERGER, A. 1953. Transactions of the American Philosphical Society. Encyclopedic Dictionary of Roman Law. Philadelphia: The American Philosophical Society.

BERKHOF, L. 1976. Systematic theology. London: Cox \& Wyman.

BOUWMAN, H. 1970a. Gereformeerd kerkrecht. Eerste Deel. Kampen: Kok.

CALVIN, J. 1848. Commentary on the Epistles of Paul the apostle to the Corinthians. Vol. 1. Translated from the original Latin, and collated with the author's French version, by the Rev. John Pringle. Edinburgh: Printed for the Calvin Translation Society.

CALVYN, J. 1991. Institusie van die Christelike Godsdiens. Boek IV. Vertaal deur H.W. Simpson. Potchefstroom: Calvyn Jubileum Boekefonds.

COENEN, 1986. Call. (In Dictionary of New Testament Theology. Volume 1. Grand Rapids: Zondervan. p. 271-276.)

DE BRES, G. 1561. Die Nederlandse geloofsbelydenis. (In Die berymde Psalms. Kaapstad: NG Kerkuitgewers. p. 488-516.)

DU PLESSIS, L.M. 1997. Menseregte in die skadu's en skanse van die ivoortoring. Stellenbosch law review, (2):181-191. 
DU PLOOY, A. le R. 1979. Ekklésia en meerdere vergaderinge. Potchefstroom: $\mathrm{PU}$ vir CHO. (M.A.-verhandeling.)

DU PLOOY, A. le R. 1982. Kerkverband: 'n Gereformeerde kerkregtelike studie. Potchefstroom: PU vir CHO. (Th.D.-proefskrif.)

DU PLOOY, A. le R. 1998. The keys of the Kingdom as paradigm for building up the church in reformed church government. In die Skriflig, 32(1):53-68.

DU PLOOY, A. le R. 2002. Kerke se interne verbandsreg en die arbeidswetgewing. Advies aan die Konvent van Gereformeerde Kerke in SuidAfrika. p. 1-6. (Ongepubliseer.)

FORMULIER

kyk FORMULIER VIR DIE BEVESTIGING VAN BEDIENAARS VAN DIE WOORD

FORMULIER VIR DIE BEVESTIGING VAN BEDIENAARS VAN DIE WOORD. 2001. (In Die Psalmboek. Wellington: NG Kerkuitgewers. p. 137-142.)

GEREFORMEERDE KERKE IN SUID-AFRIKA. KERKORDE. 1998. Kerkordeboekie van die Gereformeerde Kerke in Suid-Afrika. Potchefstroom: Administratiewe Buro van die GKSA.

GILDENHUYS, J. 2001. An assessment of constitutional guarentees of religious rights and freedoms in South Africa. Stellenbosch: University of Stellenbosch. (LL.D. dissertation.)

GOUMAZ, L. 1964. Het ambt bij Calvijn: een samenvatting naar zijn commentaren op het Nieuwe Testament. Vertaald en ingeleid door K. Deddens. Franeker: Wever.

GROGAN, J. 2000. Workplace law. 5th ed. Kenwyn: Juta.

GROGAN, J. 2003. Workplace law. 6th ed. Kenwyn: Juta.

$\mathrm{HK}$

kyk URSINUS, Z. \& OLEVIANUS, C.

JORDAAN, B. \& RYCROFT, A. 1994. Handleiding tot die Suid-Afrikaanse Arbeidsreg. Kenwyn: Juta.

$\mathrm{KO}$

kyk GEREFORMEERDE KERKE IN SUID-AFRIKA. KERKORDE

MILNER, B.C. 1970. Calvin's doctrine of the church. Leiden: Brill.

NEDERDUITSE GERFORMEERDE KERK KERKORDE. 1999. Kerkorde, bepalinge en reglemente van die Nederduitse Gereformeerde Kerk in SuidAfrika. Kaapstad: LuxVerbi.

NGB

NGKO

kyk DE BRES, G.

kyk NEDERDUITSE GEREFORMEERDE KERK. KERKORDE

OLIVIER, M. 2002. The South African Constitution and freedom of religion: some labour law imperatives and implications. Nederduitse Gereformeerde teologiese tydskrif, 43(3 \& 4):531-542.

PAUL, R.S. 1965. Ministry. Grand Rapids: Eerdmans.

PEL, P.T. et al. 1991. Rechtspositie en tractement van de predikant. Zwolle: GMV.

PHILIP, J. 1979. The call to the ministry. (In Stein, J., ed. Ministers for the 1980's. Edinburgh: Handsel. p. 22-31.)

PIENAAR, G. 1982. Die gemeenregtelike regspersoon in die Suid-Afrikaanse Privaatreg. Potchefstroom: PU vir $\mathrm{CHO}$ (LL.D.-proefskrif.)

PIENAAR, G. 1986. Die regsposisie van die Gereformeerde Kerke in SuidAfrika. Potchefstroom: EFJS. 
POLMAN, A.D.R. s.a. Onze Nederlandse Geloofsbelijdenis: verklaard uit het verleden gekonfronteerd met de heden. Deel 4. Franeker: Wever.

PONT, A.D. 1981. Die historiese agtergronde van ons kerklike reg. Deel 1. Pretoria: HAUM.

RICHEL, P.J. 1942. Het kerkbegrip van Calvijn. Franeke: Wever.

SILLEVIS SMITT, P.A.E. 1910. De organiastie van de Christelijke kerk in den apostolischen tijd. Rotterdam: De Vries.

SMELIK, E.L. 1973. De brieven van Paulus aan Timotheus, Titus en Filemon: de wegn der kerk. (In Klijn, A.F.J., red. De prediking van het Nieuwe Testament. Nijkerk: Callenbach.)

SMIT, C.J. 1984a. Kerkorde en belydenis. In die Skriflig, 18(70):41-46.

SMIT, C.J. 1984b. Tot lof van die kerkorde ... in sy dienskneggewaad. In die Skriflig, 18(71):37-44.

SMIT, C.J. 1984c. God se orde vir sy kerk. Pretoria: NG Kerkboekhandel.

SMIT, C.J. 1985. Kerkreg en kerkorde in die lig van God se reg vir sy kerk. Potchefstroom: PU vir CHO. (Th.D.-proefskrif.)

SMIT, J. 2001. 'n Gereformeerd-kerkregtelike beoordeling van die predikant se verbintenis aan die plaaslike kerk. Potchefstroom: PU vir CHO (Th.M.verhandeling.)

SMIT, J. 2006. Die kerk se regsposisie in Suid-Afrika in die lig van godsdiensvryheid - gereformeerd-kerkregtelik gesien. Nederduitse Gereformeerde teologiese tydskrif, 47(3 \& 4):633-551.

SMIT, J. 2007. Die beroepsbrief in die Gereformeerde Kerk in Suid-Afrika - 'n kontraktuele werksaanbod? In die Skriflig, 41(4):571-600.

SPOELSTRA, B. 1971. Vrou en amp en die amp in die algemeen. In die Skriflig, 18(5):25-44.

SPOELSTRA, B. 1989. Gereformeerde kerkreg en kerkregering: 'n handboek by die Kerkorde. Hammanskraal: Hammanskraalse Teologiese Skool van die Gereformeerde Kerke in Suid-Afrika.

URSINUS, Z. \& OLEVIANUS, C. 1563. Die Heidelbergse Kategismus of onderwysing in die Christelike leer. (In Die berymde Psalms. 1976. Kaapstad: NG Kerkuitgewers. p. 521-566.)

VAN BRUGGEN, J. 1984. Ambten in de Apostolische Kerk: een exegetisch mozaïek. Kampen: Kok.

VAN DER LINDE, G.P.L. 1965. Grondbeginsels van die Presbiteriale kerkregeringstelsel. Potchefstroom: Pro Rege.

VAN DER LINDE, G.P.L. 1978. Die beoefening van die kerkreg in die Gereformeerde Kerk in SA sedert 1859. In die Skriflig, 12(48):52-72.

VAN DER LINDE, G.P.L. 1980. Die Kerkregeringstelsel. Diktaat: Kerkreg II. Potchefstroom: $\mathrm{PU}$ vir $\mathrm{CHO}$.

VAN DER LINDE, G.P.L. 1983. Die kerkorde - 'n verklaring van die Gereformeerde Kerkorde. Potchefstroom: Potchefstroomse Teologiese Publikasies.

VAN DER LINDE, G.P.L. 1987. Die diens van die Woord in die kerk. In die Skriflig, 21(83):19-27.

VAN DER WALT, J.J. 1976. Christus as Hoof van die kerk en die presbiteriale kerkregering. Potchefstroom: Pro Rege.

VAN GENDEREN, J. 1982. De ouderling als ambtsdrager: een handreiking aan de ouderling. (In Koole, D. \& Velema, W.H., red. Uit liefde tot Christus en zijn gemeente. Tweede druk. Kampen: Kok. p. 56-70.)

VAN GINKEL, A. 1975. De ouderling. Amsterdam: Ton Bolland. 
VAN ITTERZON, G.P. 1974. Het kerklijke amp in geding. (In Van Dyk, M.P., red. Theologie en gemeente. Nr. 10. Kampen: Kok.)

VAN'T SPIJKER, W. 1970. De ambten bij Martin Bucer. Kampen: Kok.

VAN'T SPIJKER, W. 1987. De kerkorde van 1578. (In Nauta, D. \& Van Dooren, J.P., red. De Nationale Synode van Dordrecht 1578. Amsterdam: Buijten \& Schippenheijn. p. 126-141.)

VAN'T SPIJKER, W. 1990. De kerk bij Calvijn: theocratie. (In Van't Spijker, W. et al. De kerk: wezen, weg en werk van de kerk naar reformatorische opvatting. Kampen: De Groot Goudriaan. p. 143-162.)

VAN'T SPIJKER, W. 2001a. Calvyn. Referaat gelewer te Potchefstroom. (Ongepubliseer.)

VAN'T SPIJKER, W. 2001b. Luther. Referaat gelewer te Potchefstroom. (Ongepubliseer.)

VERSTEEG, J.P. et al. 1982. Nieuwtestamentisch profiel van de ouderling. (In Koole, D. \& Velema, W.H., red. Uit liefde tot Christus en zijn gemeente. 2e druk. Kampen: Kok. p. 11-55.)

VISSER, J. 1982. Die tug oor ampsdraers. Potchefstroom: PU vir CHO. (Th.D.proefskrif.)

VORSTER, J.D. s.a. Die beroepstelsel. Pretoria: NG Kerkuitgewers.

VORSTER, J.M. 1999. An introduction to Reformed Church polity. Potchefstroom: Potchefstroomse Teologiese Publikasies.

\section{Hofsake}

Church of the Province of Southern Africa (Diocese of Cape Town) $v$ KVBA \& others [2001] 11 BLLR 1213 (LC)

Schreuder v Die Nederduitse Gereformeerde Kerk Wilgespruit and other. 1999 20 ILJ 1936 (LC)

South African National Defence Union v Minister of Defence 1999 BCLR 713 (LC)

\section{Wette}

Constitution of the Republic of South Africa, Act 108 of 1996

Die Wet op Arbeidsverhoudinge 66 van 1995

Die Wet op Basiese Dienvoorwaardes 75 van 1997

Die Wet op Gelyke Indiensneming 55 van 1998

GW see Constitution of the Republic of South Africa

\section{Kernbegrippe:}

arbeidsreg

Kerkorde

predikant

werknemer

\section{Key concepts}

Church order

employee

labour law

minister of religion 